Journal of Applied Biology \& Biotechnology Vol. 7(01), pp 060-064, January-February, 2019

Available online at http://www.jabonline.in

DOI: $10.7324 / J A B B .2019 .70111$

(cc) BY-NC-SA

\title{
Bioluminescence of Vibrio fischeri: A novel application for PSP quantification
}

\author{
Mohamed Blaghen ${ }^{1,2}$, Abdel-hamid Abdallah Abakar ${ }^{1}$ \\ ${ }^{1}$ Laboratory of Microbiology, Pharmacology, Biotechnology, and Environment, Faculty of Sciences, Aïn Chock, Hassan II University, Casablanca, Morocco. \\ ${ }^{2}$ Laboratory of Plant Biotechnology, Ecology and Ecosystem Valorization, Faculty of Sciences El Jadida, Chouaïb Doukkali University, El Jadida, Morocco.
}

\begin{tabular}{|c|c|}
\hline ARTICLE INFO & ABSTRACT \\
\hline $\begin{array}{l}\text { Article history: } \\
\text { Received on: June 28, } 2018 \\
\text { Accepted on: August 27, } 2018 \\
\text { Available online: January 20, } 2019\end{array}$ & $\begin{array}{l}\text { Paralytic Shellfish Poison (PSP) are the most harmful neurotoxins create a serious public health problem. It is } \\
\text { important to assess PSP in Shellfish destined for human consumption. However, recommended methods have } \\
\text { some limitations for example in the case of Mouse Bioassay (MBA) showed a low sensitivity and reproducibility, } \\
\text { and undesirability for ethical reasons; while physicochemical techniques rest expensive and time-consuming. } \\
\text { The main objective of this study, after discovering that PSP inhibited the luminescence of Vibrio fischeri, was }\end{array}$ \\
\hline $\begin{array}{l}\text { Key words: Method, } \\
\text { Bioluminescence, Vibrio fischeri, } \\
\text { Acanthocardia Tuberculatum, } \\
\text { bivalve, PSP, STX. }\end{array}$ & $\begin{array}{l}\text { the quantification of PSP by using Bioluminescence Inhibition Assay (BIA), and comparing the results obtained } \\
\text { with those determined by MBA and LC-MS. Bivalve used were collected from Corniche Martil, Kabila, and } \\
\text { Oued Laou, along with the Mediterranean coast of Morocco in Mars-2015. Results showed a weak correlation } \\
\text { between LC-MS and MBA with } \mathrm{r}=0.11 \text {, while, the correlation between LC-MS and BIA was very strong with } \\
\mathrm{r}=0.97 \text {, which suggests that, BIA could offer an interesting additional assessment of PSP risk. In addition, after } \\
\text { seen its rapidity, ease, reliability, sensitivity, reproducibility, and cost-effectiveness, it would be eligible to use } \\
\text { for monitoring in surveillance programs. }\end{array}$ \\
\hline
\end{tabular}

\section{INTRODUCTION}

Some species of dinoflagellates such as Alexandrium, Gymnodinium, and Pyrodinium produce Paralytic Shellfish Poisoning (PSP) [1,2]. PSP are ubiquitous along coasts, which pass by marine food chain through vector organisms accumulate them by feeding on dinoflagellates [3]. Among PSP, the Saxitoxin (STX) is discovered in 1975 [1] and is the most potent aquatic biotoxins, which caused a huge number of poisoning case in humanity due to respiratory failure [4-5]. Up to know, 57 analogs of STX are known, all exhibiting different toxicities [1]. Consequently, many countries have decided to ensure bivalve destined for consumption must not exceed the permitted threshold of PSP in shellfish, is $800 \mathrm{mg}$ STXs equivalents (STX eq) per $\mathrm{kg}$ of shellfish tissue [5]. However, among the official methods used to monitor PSP were principally the Mouse Bioassay (MBA) and physicochemical techniques. MBA was discovered in the 1930s, and used by the Association of Official Analytical Chemists (AOAC) international, European Union (EU) legislation and the United States Food and Drug

\footnotetext{
${ }^{*}$ Corresponding Author

Mohamed Blaghen, Laboratory of Microbiology, Pharmacology, Biotechnology, and Environment, Faculty of Sciences, Aï Chock, University Hassan II, Casablanca, Morocco.

E-mail:blaghen.m@ucd.ac.ma
}

Administration as an official method for PSP in shellfish monitoring [6-8]. MBA method is easy to operate and rapid to assess a total toxicity [9-11]. However, this method has some limitations, including low sensitivity and reproducibility [12] and also its undesirability for ethical reasons [14], was conducted the search for alternative physicochemical techniques for PSP monitoring. However, these physicochemical techniques seem to be very expensive, useful mostly for identified PSP in samples because their operations depend on the sample toxicity, require well-trained persons for their operations, and consume more time particularly when analyzing a huge amount of samples [3,30-33]. Among these techniques, we have thin layer chromatography [13], capillary electrophoresis [15], immunological based method [16-18], High Performance Liquid Chromatography with either pre- or postcolumn derivatization with Fluorescence Detection (HPLC-FLD) $[5,19,20]$, Liquid Chromatography coupled to Mass Spectrometry (LC-MS), Hydrophilic Interaction Liquid Chromatography coupled to tandem Mass Spectrometry (HILIC) LC-MS/MS [21-26]. HPLCFLD called Lawrence method which the detection was based to the conversion of PSP into fluorescent derivatives [27], has been validated and adopted by AOAC as an official technique, This automated method was permitted sensitive and selective toxin determination [28]; LC-MS that has been adopted by EU as the standard method in PSP assessment, has attracted more attention for its high performance of qualitative, quantitative and selective analysis [29] to monitor PSP 
in shellfish. This paper presents, after discovered that PSP inhibited the luminescence of Vibrio fischeri ( $V$. fischeri), the utilization of Bioluminescence Inhibition Assay (BIA) for PSP quantification. This method was therefore based on the inhibition of the luminescence of $V$. fischeri by PSP since the rate of inhibition of bioluminescence depended on PSP concentration. According to the scientific literature, BIA has never been used to quantify PSP and, therefore we have used the study of the inhibition of bioluminescence by PSP for implementing a new technique for PSP quantification.

\section{MATERIALS AND METHODS}

\subsection{Biological materials}

Bacteria: Vibrio fischeri strain NRRL-B-11177.

Cockle: Acanthocardia tuberculatum.

\subsection{Bacterial growth media}

V. fischeri was grown in a modified Luria-Bertani Salt (LBS) medium as described in 2017 by A. A. Abdel-hamid et al. (10 g nutrient broth, $5 \mathrm{~g}$ yeast extract, $20 \mathrm{~g} \mathrm{NaCl}, 50 \mathrm{ml} 1 \mathrm{M}$ Tris buffer, $\mathrm{pH} 7.5 \pm 0.02$, in one liter of distilled water at $25^{\circ} \mathrm{C}$ ) [38]. All products were purchased from Biokar Diagnostics.

\subsection{Bioassays and Statistical analysis}

PSP assessment was carried out by MBA according to AOAC, LC-MS, and BIA.

BIA performed in 96-well microplate format using Luminoskan Ascent Luminometer (LAL). Bacteria growth was determined using spectrophotometer (UV-Visible) at the optical density of $600 \mathrm{~nm}$ $\left(\mathrm{OD}_{600 \mathrm{~nm}}\right)$. All data were analyzed using Graph-PadTM Prism. Values are means \pm standard errors. All experiments were done in triplicate. Bioluminescence inhibition was determined according to the equation below as described by A. A. Abdel-hamid et al. [38].

$$
\begin{aligned}
\% \text { light inhibition } & =100-100 \times\left(\mathrm{IT}_{15} / \mathrm{KF} \times \mathrm{IT}_{0}\right) \\
\mathrm{KF} & =\mathrm{IC}_{15} / \mathrm{IC}_{0}[38] .
\end{aligned}
$$

\subsection{Sample}

Cockles and other bivalve were collected from Kabila, Corniche Martil, and Oued Laou, along with the Mediterranean coast of Morocco in Mars 2015 (Fig. 1). Samples collected were kept at $-20^{\circ} \mathrm{C}$ prior to PSP extraction and analysis. All samples were thawed at $4{ }^{\circ} \mathrm{C}$ prior to PSP extraction.

An STX standard $(66,3 \mu \mathrm{M})$ was obtained from Laboratory of the Marine Biotoxins, National Institute of Halieutic Research, Casablanca, Morocco.

\subsection{Extraction of PSP}

Extraction of PSP form cockles was done in accordance with the previously published protocol in 2010 by CK Wong et al. [3].

\subsection{MBA}

Albinos mice (20 $\pm 2 \mathrm{~g}$ ) were obtained from Laboratory of the Marine Biotoxins, National Institute of Halieutic Research, Casablanca, Morocco. They were acclimated for $24 \mathrm{~h}$ and housed in a controlled environment at $24 \pm 2{ }^{\circ} \mathrm{C}, 54-56 \%$ humidity. PSP assessment by MBA was performed in accordance with the official AOAC procedure of PSP assessment [39].

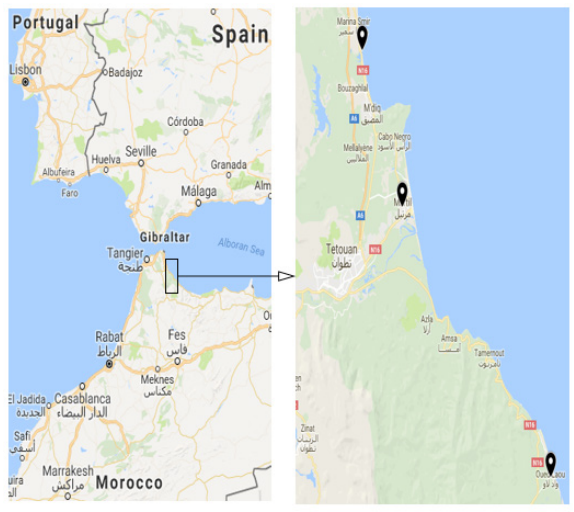

Figure 1: Sampling sites.

\subsection{LC-MS}

PSP in cockles were quantified by LC-MS in accordance with the previously published protocol in 2005 by Staack et al. [40].

\subsection{BIA}

Dilutions $(1: 1.25,1: 1.5,1: 1.75,1: 2,1: 2.5,1: 3,1: 3.5,1: 4)$ of PSP of all samples were prepared in $2 \% \mathrm{NaCl}$ at $\mathrm{pH} 3.5 .0 .1 \mathrm{ml}$ of each PSP dilution was added into different wells in duplicate, supplemented with $0.1 \mathrm{ml}$ of bacterial suspension by automatic dispensing within LAL testing chamber. The bioluminescence was recorded after the microplate was automatically shacked. The signal of the light was measured in the first contact at $25^{\circ} \mathrm{C}$ in duplicate.

The quantification of PSP in cockles was done according to following procedure:

- Serial dilutions $(1: 1.25,1: 1.5,1: 1.75,1: 2,1: 2.5,1: 3,1: 3.5,1: 4)$ of PSP were prepared in $2 \% \mathrm{NaCl}(\mathrm{pH} 3.5)$.

- $2 \% \mathrm{NaCl}(\mathrm{pH} 3.5)$ served as a control and solution of dilution.

- Extract and diluted PSP were incubated at $25^{\circ} \mathrm{C}$ for $30 \mathrm{~min}$.

- Luminescent bacteria $V$. fischeri were reconstituted and then incubated at $25^{\circ} \mathrm{C}$, by shaking $(250 \mathrm{rpm})$ and aerating $(600 \mathrm{ml} /$ $\min$ ) for $22 \mathrm{~h} \mathrm{[38].}$

- $0.1 \mathrm{ml}$ of each diluted PSP solution was added into different wells in duplicate, supplemented with the same volume of bacterial suspension by an automatic dispensing and shacked within LAL testing chamber.

- The signal of the light was directly and automatically measured,

The Standard of STX with different concentrations $(0.16,0.33,0.99$, $1.65 \mu \mathrm{M}$ ) was analyzed using the same procedure.

\section{9. pH solutions}

$\mathrm{pH} 1-14$ solutions were prepared in $2 \% \mathrm{NaCl}$ by using $\mathrm{HCl} 5 \mathrm{~N}, \mathrm{NaOH}$ $0.1 \mathrm{~N}, \mathrm{HCl} 0.1 \mathrm{~N}$ and $\mathrm{NaOH} 5 \mathrm{~N}$.

\section{RESULTS AND DISCUSSION}

Nowadays the detection of toxins in bivalve is becoming more necessary and frequent. Therefore, it is very important to use a method that is easy, rapid, sensitive and cost-effective to evaluate PSP in bivalve. BIA is based on $V$. fischeri a marine gram-negative bacterium, 
widely used to evaluate toxicity. The best conditions for intensity and stability of luminescence emission and growth of the bacteria were determined in accordance with the previously published work in 2017 by A. A. Abdel-hamid et al. [38]. These best conditions had let us to evaluate the toxicity of PSP in cockles.

The goal of this work was to investigate the applicability of the inhibition of $V$. fischeri by PSP for the PSP quantification. The Cockles were collected from Kabila, Corniche Martil, and Oued Laou, along with the Mediterranean coast of Morocco. $100 \mathrm{~g}$ of shellfish tissues of each sample was crushed then homogenized and boiled gently with stirring for $5 \mathrm{~min}$ and then brought to $200 \mathrm{ml}$ with distilled water. Each boiled homogenate was centrifuged at $3000 \mathrm{x} \mathrm{g}$ for $10 \mathrm{~min}$. supernatants were adjusted to $\mathrm{pH} 3.5$ and kept at $4{ }^{\circ} \mathrm{C}$ prior to testing.

Firstly, all samples were tested by MBA in accordance with the official AOAC procedures for PSP [39], before analyzing by LC-MS and BIA.

For MBA, three mice were weighed and injected intraperitoneally with $1 \mathrm{ml}$ of PSP extract (the same extract used for LC-MS analysis and BIA). The treated mice were then closely observed. The median survival time was adopted for toxicity (MU) calculation. The values of toxicity were expressed in terms of $\mu \mathrm{g}$ STX eq/100 $\mathrm{g}$ tissues, based on AOAC method, thereafter converted to $\mu \mathrm{M}$. All the three samples showed toxicity to mice. The most sample toxic to mice was that's from Oued Laou, its calculated toxicity value was $12.80 \mu \mathrm{M}$, the less toxic extract was that from Kabila with a toxicity value of $6.30 \mu \mathrm{M}$, while Corniche Martil extract showed a toxicity $(11.20 \mu \mathrm{M})$ near to the toxicity of Oued Laou (Table 1).

Table 1: STX equivalent values obtained using MBA, LC-MS and BIA. Values expressed in $\mu \mathrm{M}$.

\begin{tabular}{cccc} 
Sampling site & MBA* $^{*}$ & LC-MS & BIA** $^{* *}$ \\
Corniche Martil & $11.20 \pm 1,20$ & 2.77 & $2.26 \pm 0,01$ \\
Kabila & $06.30 \pm 0,70$ & 1.31 & $1.56 \pm 0,02$ \\
Oued Laou & $12.80 \pm 1,30$ & 0.98 & $1.1 \pm 0,01$ \\
\hline
\end{tabular}

*MBA: Mouse Bioessay; ** BIA: Bioluminescence Inhibition Assay.

Secondly, all samples were analyzed by LC-MS. and STX at concentrations of $0.16,0.33,0.99,1.65 \mu \mathrm{M}$ was used to obtain the standard curve.

According to the results obtained using LC-MS, a sample from Corniche Martil showed the highest concentration $(2.77 \mu \mathrm{M})$ of STX compared to those from Kabila and Oued Laou whose concentrations were 1.31 and $0.98 \mu \mathrm{M}$ respectively (Table 1 ).

Before analyzing samples, as all the samples were adjusted to $\mathrm{pH} 3.5$ based on AOAC method [39]. It is important to see the effects of $\mathrm{pH}$ on the bacteria bioluminescence. Indeed $\mathrm{pH}$ between 1 and 14 was tested. Results showed that the $\mathrm{pH} 1, \mathrm{pH} 13$ and $\mathrm{pH} 14$ inhibited totally the luminescence from the first contact, whereas $\mathrm{pH} 2$ has begun to inhibit the light after $15 \mathrm{~min}$ of incubation, meanwhile from $\mathrm{pH} 3$ to $\mathrm{pH} 12$ did not inhibit the bioluminescence (Fig. 2).

Thirdly, all samples were analyzed using BIA. The STX standard was used to obtain the standard curve, Analyzed concentrations of the saxitoxin were $0.16,0.33,0.99,1.65 \mu \mathrm{M}$. (Fig. 3).

All PSP extracts from different sites showed bioluminescence inhibition. This inhibition decreased with dilution factor (Fig. 4).

The concentration of PSP of each sample was calculated according to the standard curve of STX. The result showed that the sample from Corniche Martil which its PSP concentration value was 2.26 $\mu \mathrm{M}$ of STX eq inhibited most the light of the bacteria. Samples from Kabila and Oued Laou showed the PSP concentration values of 1.56 and $1.1 \mu \mathrm{M}$ of STX eq respectively, nearly the same inhibition of the bioluminescence while there was a significant difference between results obtained using LC-MS and MBA (Fig. 5) (Table 1).

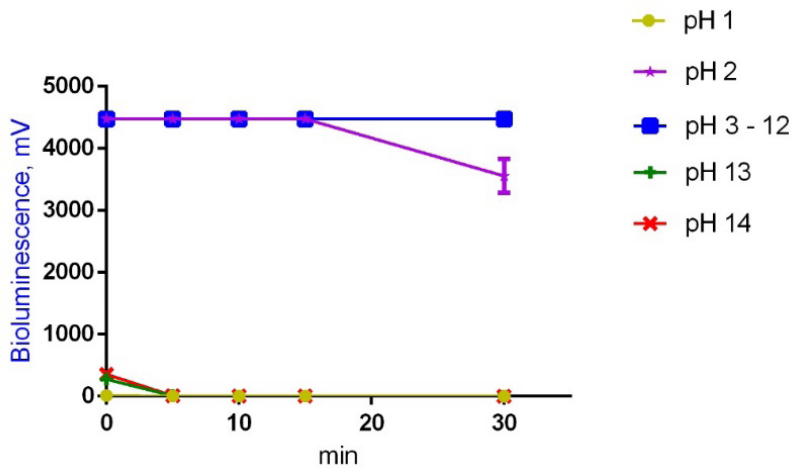

Figure 2: Measurements of luminescence of $V$. fischeri at different $\mathrm{pHs}$. Measured directly after first contact, $5 \mathrm{~min}, 10 \mathrm{~min}, 15 \mathrm{~min}$ and $30 \mathrm{~min}$.

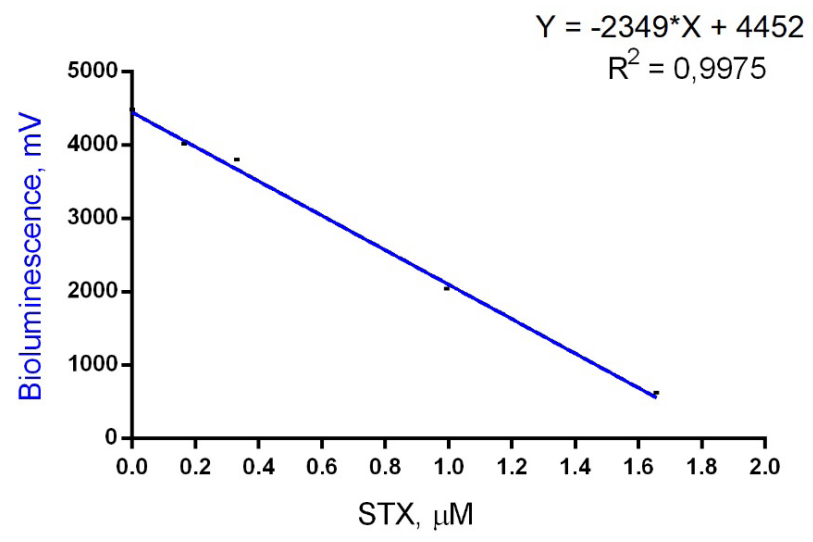

Figure 3: Standard curve of STX obtained by BIA.

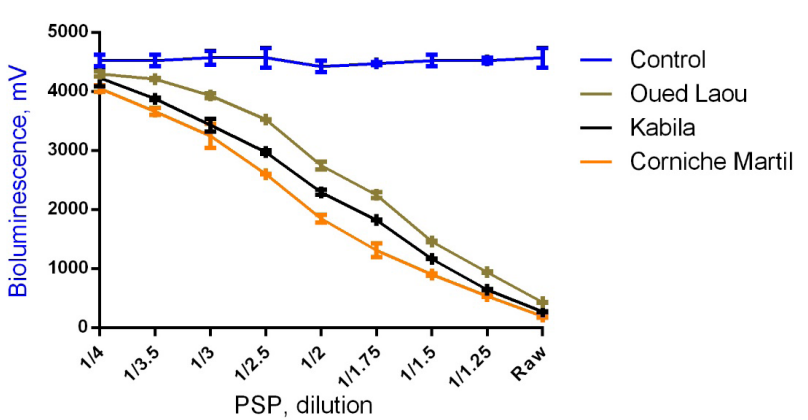

Figure 4: Measurements of luminescence of $V$. fischeri exposed to dilutions of PSP from Oued Laou, Kabila, and Corniche Martil. Measured directly after the first contact. $2 \% \mathrm{NaCl}$ served as a control and diluent.

According to LC-MS, the results were 2.77, 1.31 and $0.98 \mu \mathrm{M}$ STX for Corniche Martil, Kabila and Oued Laou respectively. Meanwhile, MBA results were 11.2, 6.3 and $128 \mu \mathrm{M}$ STX equivalent for Corniche Martil, Kabila, and Oued Laou respectively (Fig. 5) (Table 1). Thus, 
the correlation between LC-MS and MBA was very weak with $r=0.11$ (Fig. 6).

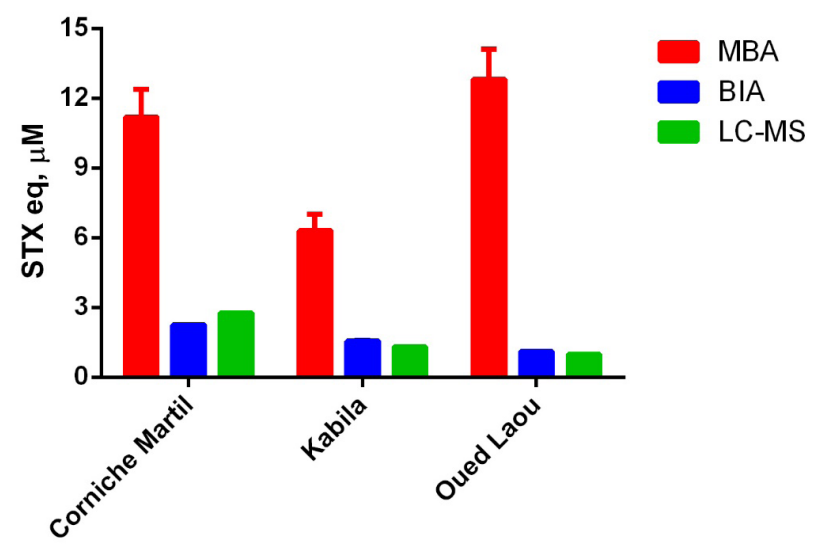

Figure 5: Comparison of the three methods (BIA, LC-MS, and MBA) used for the assessment of PSP from Corniche Martil, Oued Laou, and Kabila. Values were expressed as $\mu \mathrm{M}$ of STX eq.

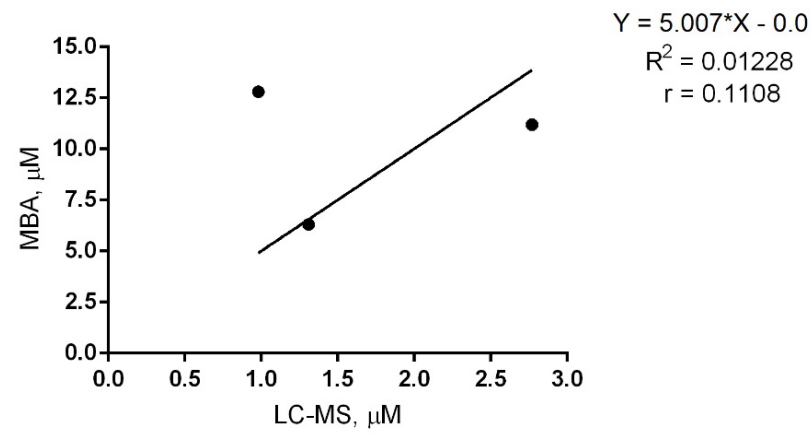

Figure 6: Correlation between LC-MS and MBA for analysis of PSP in cockles expressed in STX equivalent (Number of compared samples $=3$ ).

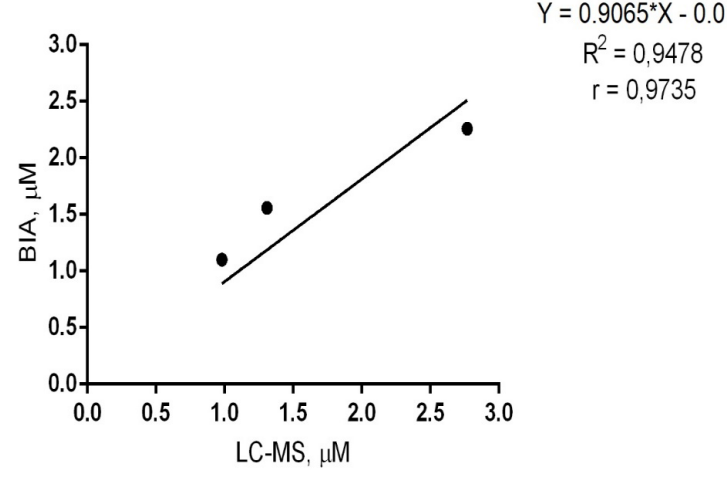

Figure 7: Correlation between LC-MS and BIA for analysis of PSP in cockles expressed in STX eq (Number of compared samples $=3$ ).

However, PSP concentrations obtained by BIA were 2.26, 1.56 and $1.1 \mu \mathrm{M}$ STX equivalent for Corniche Martil, Kabila and Oued Laou respectively. Thus, these results were significantly comparable with those obtained using LC-MS (Fig. 5) with a very strong correlation with $r=0.97$ (Fig. 7).

As MBA has some limitations, including low sensitivity [12] and reproducibility, and the undesirability for ethical reasons [14]; studies showed that application of a rapid method of PSP detection would reduce experimental mice by $30-60 \%$ [41,42]. Also as physicochemical techniques such as LC-MS and HPLC-FLD, seem to be very expensive, useful mostly for identified PSP in samples, require welltrained persons and consume more time particularly when analyzing a huge amount of samples [3,30-33]. Moreover, as BIA is very easy to use, rapid and cheap, in addition to its great correlation with LC-MS with $r=0.97$. Thus, it could offer an additional quantification of PSP in bivalves.

\section{CONCLUSION}

According to the results obtained during this study, all samples presented toxicity to mice, inhibited the light of $V$. fischeri. There was a significant difference between results obtained using LC-MS and MBA, the correlation was very weak with $r=0.11$. However, the expressed PSP concentrations obtained by BIA were 2.26, 1.56 and $1.1 \mu \mathrm{M}$ STX eq for Corniche Martil, Kabila and Oued Laou respectively that were significantly comparable with those obtained using LC-MS which the STX concentrations were 2.77, 1.31 and $0.98 \mu \mathrm{M}$ for Corniche Martil, Kabila and Oued Laou respectively, with a strong correlation with $\mathrm{r}$ $=0.97$. Based on these results, BIA additionally may be used for the assessment of PSP risk. Thus, its rapidity, ease, reliability, sensitivity, reproducibility, and cost-effectiveness would eligible its use for PSP monitoring in surveillance programs.

\section{ACKNOWLEDGMENTS}

Gratefully thank Dr. Hamid Taleb at Laboratory of Marine Biotoxins, National Institute of Halieutic Research, Casablanca, Morocco for providing STX Standard and Albinos mice.

\section{REFERENCES}

1. Wiese M, D'Agostino PM, Mihali TK, et al. Neurotoxic Alkaloids: STX and Its Analogs. Mar Drugs 2010; 8:2185-2211.

2. Vale C, Alfonso A, Vieytes MR, et al. In Vitro and in Vivo Evaluation of Paralytic Shellfish Poisoning Toxin Potency and the Influence of the pH of Extraction. Anal Chem 2008; 80:1770-1776.

3. Wong C-K, Hung P, Ng EAL, et al. Operational application of a rapid antibody-based detection assay for first line screening of paralytic shellfish toxins in shellfish. Harmful Algae 2010; 9:636-646.

4. Anderson DM, Alpermann TJ, Cembella AD, et al. The globally distributed genus Alexandrium: Multifaceted roles in marine ecosystems and impacts on human health. Harmful Algae 2012; 14:10-35.

5. Lawrence JF, Niedzwiadek B, Menard C. Quantitative determination of paralytic shellfish poisoning toxins in shellfish using prechromatographic oxidation and liquid chromatography with fluorescence detection: collaborative study. J AOAC Int 2005; 88:1714-1732.

6. Lehane L. Paralytic shellfish poisoning: a potential public health problem. Med J Aust 2001; 175:29-31.

7. Lehane L, Australia. Dept. of Agriculture F, Animal FNO of, et al. Paralytic shellfish poisoning: a review. Canberra: Animal Health Science and Emergency Management Branch, Agriculture, Fisheries and Forestry.

8. Sommer H, Meyer KF. Paralytic Shell-Fish Poisoning. Arch Pathol 1937; 24:560-98.

9. Bricelj VM, Shumway SE. Paralytic Shellfish Toxins in Bivalve Molluscs: Occurrence, Transfer Kinetics, and Biotransformation. Rev Fish Sci 2010; 6:315-383.

10. Park DL, Guzman-Perez SE, Lopez-Garcia R. Aquatic biotoxins: design and implementation of seafood safety monitoring programs. Rev Environ Contam Toxicol 1999; 161:157-200.

11. Fernández ML, Cembella AD. Mammalian bioassays. 1995. In: 
Hallegraeff GM, Anderson DM, Cembella AD, eds. Manual on Harmful Marine Microalgae. UNESCO, France 213-228.

12. Van Dolah FM, Ramsdell JS. Review and assessment of in vitro detection methods for algal toxins. J AOAC Int 2001; 84:1617-1625.

13. Li Z-Y, Chen J-H, Li X, et al. Rapid Screening, Identification of Paralytic Shellfish Poisoning Toxins in Red Tide Algae Using Hydrophilic Interaction Chromatography-High Resolution Mass Spectrometry with an Accurate-Mass Database. Chin J Anal Chem Chin VERSION 2013; 41:979.

14. Botana LM, Vilario N, Alfonso A, et al. The problem of toxicity equivalent factors in developing alternative methods to animal bioassays for marine-toxin detection. TrAC Trends Anal Chem 2010; 29:1316-1325.

15. Jaime E, Hummert C, Hess P, et al. Determination of paralytic shellfish poisoning toxins by highperformance ion-exchange chromatography. J Chroma - togr, 2001; 43-49.

16. Fonfría ES, Vilariño N, Campbell K, et al. Paralytic Shellfish Poisoning Detection by Surface Plasmon Resonance-Based Biosensors in Shellfish Matrixes. Anal Chem 2007; 79:6303-6311.

17. Campbell K, Haughey SA, van den Top H, et al. Single laboratory validation of a surface plasmon resonance biosensor screening method for paralytic shellfish poisoning toxins. Anal Chem 2010; 82:29772988.

18. Haughey SA, Campbell K, Yakes BJ, et al. Comparison of biosensor platforms for surface plasmon resonance based detection of paralytic shellfish toxins. Talanta 2011; 85:519-526.

19. Oshima Y. 1995a. Post-column derivatization HPLC methods for paralytic shellfish poisons. In: Hallegraeff GM, Anderson DM, Cembella AD, eds. Manual on Harmful Marine Microalgae. UNESCO, France 81-94.

20. Oshima Y. Postcolumn derivatization liquid chromatographic method for paralytic shellfish toxins. J AOAC Int 1995b; 78:528-532.

21. Turrell E, Stobo L, Lacaze J-P, et al. Optimization of hydrophilic interaction liquid chromatography/mass spectrometry and development of solid-phase extraction for the determination of paralytic shellfish poisoning toxins. J AOAC Int 2008; 91:1372-1386.

22. Sayfritz SJ, Aasen JAB, Aune T. Determination of paralytic shellfish poisoning toxins in Norwegian shellfish by liquid chromatography with fluorescence and tandem mass spectrometry detection. Toxicon 2008; 52:330-340.

23. Zhuo L, Yin $\mathrm{Y}, \mathrm{Fu} \mathrm{W}$, et al. Determination of paralytic shellfish poisoning toxins by HILIC?MS/MS coupled with dispersive solid phase extraction. Food Chem 2013; 137:115-121.

24. Boundy MJ, Selwood AI, Harwood DT, et al. Development of a sensitive and selective liquid chromatography? mass spectrometry method for high throughput analysis of paralytic shellfish toxins using graphitised carbon solid phase extraction. J Chromatogr A 2015; 1387:1-12.

25. Dell'Aversano C, Hess P, Quilliam MA. Hydrophilic interaction liquid chromatography--mass spectrometry for the analysis of paralytic shellfish poisoning (PSP) toxins. J Chromatogr A 2005; 1081:190-201.

26. Diener M, Erler K, Christian B, et al. Application of a new zwitterionic hydrophilic interaction chromatography column for determination of paralytic shellfish poisoning toxins. J Sep Sci 2007; 30:1821-1826.

27. Gago-Martínez A, Moscoso SA, Leão Martins JM, et al. Effect of pH on the oxidation of paralytic shellfish poisoning toxins for analysis by liquid chromatography. J Chromatogr A 2001; 905:351-357.

28. Mattarozzi M, Milioli M, Bianchi F, et al. Optimization of a rapid QuEChERS sample treatment method for HILIC-MS 2 analysis of paralytic shellfish poisoning (PSP) toxins in mussels. Food Control 2016; 60:138-145.

29. Solino L, Sureda FX, Diogne J. Evaluation of okadaic acid, dinophysistoxin-1 and dinophysistoxin-2 toxicity on Neuro-2a, NG108-15 and MCF-7 cell lines. Toxicol In Vitro 2015; 29:59-62.

30. Rodriguez LP, Vilario N, Molg J, et al. Development of a Solid-Phase Receptor-Based Assay for the Detection of Cyclic Imines Using a Microsphere-Flow Cytometry System. Anal Chem 2013; 85:23402347.

31. Turner AD, Tarnovius S, Johnson S, et al. Testing and application of a refined rapid detection method for paralytic shellfish poisoning toxins in UK shellfish. Toxicon 2015; 100:32-41.

32. Harrison K, Johnson S, Turner AD. Application of rapid test kits for the determination of paralytic shellfish poisoning (PSP) toxins in bivalve molluscs from Great Britain. Toxicon 2016; 119:352-361.

33. Ben-Gigirey B, Rodriguez-Velasco ML, Villar-Gonzalez A, et al. Influence of the sample toxic profile on the suitability of a high performance liquid chromatography method for official paralytic shellfish toxins control. J Chromatogr A 2007; 1140:78-87.

34. Parvez S, Venkataraman C, Mukherji S. A review on advantages of implementing luminescence inhibition test (Vibrio fischeri) for acute toxicity prediction of chemicals. Environ Int 2006; 32:265-268.

35. Boyd EM, Killham K, Wright J, et al. Toxicity assessment of xenobiotic contaminated groundwater using lux modified Pseudomonas fluorescens. Chemosphere 1997; 35:1967-1985.

36. Reemtsma T, Putschew A, Jekel M. Industrial wastewater analysis: a toxicity-directed approach. Waste Manag 1999; 19:181-188.

37. Devare M, Bahadir M. Biological monitoring of landfill leachate using plants and luminescent bacteria. Chemosphere 1994; 28:261-271.

38. Abdallah AA, Daher A, Belghmi K, et al. Detoxification Assessment of Inorganic Mercury by Bioluminescence of Vibrio fischeri. Res J Environ Toxicol 2017; 11:104-111.

39. AOAC, 2000. Official Method 959.08. Paralytic Shellfish Poison Biological Method. Final Action. AOAC Official Methods of Analysis, 17th edition. Gaithersburg, Maryland 59-61.

40. Staack RF, Varesio E, Hopfgartner G. The combination of liquid chromatography/tandem mass spectrometry and chip-based infusion for improved screening and characterization of drug metabolites. Rapid Commun Mass Spectrom; 19:618-626.

41. Turrell EA, Lacaze JP, Stobo L. Determination of paralytic shellfish poisoning (PSP) toxins in UK shellfish. Harmful Algae 2007; 6:438448.

42. Oshiro M, Pham L, Csuti D, et al. Paralytic shellfish poisoning surveillance in California using the Jellett Rapid PSP test. Harmful Algae 2006; 5:69-73.

How to cite this article:

Blaghen M, Abakar AA. Bioluminescence of Vibrio fischeri: A novel application for PSP quantification. J App Biol Biotech. 2019;7(01):060064. DOI: 10.7324/JABB.2019.70111 